\title{
GERENCIAMENTO DE ÁREAS CONTAMINADAS NO BRASIL: UMA ANÁLISE CRÍTICA
}

\author{
MANAGEMENT OF CONTAMINATED AREAS IN BRAZIL: A CRITICAL ANALYSIS
}

\author{
Paula Giovana Grangeiro CANARIO, Sueli do Carmo BETTINE \\ Pontifícia Universidade Católica de Campinas, Centro de Ciências Exatas, Ambientais e de Tecnologias; Programa de Pós Graduação \\ em Sistemas de Infraestrutura Urbana. Rua Professor Doutor Euryclides de Jesus Zerbini, 1516 - Pq. Rural Fazenda Santa Cândida, \\ Campinas - SP. E-mails: paulinha_ggc@hotmail.com; subettine@hotmail.com \\ Introdução \\ Origem das Áreas Contaminadas \\ Normas, Legislações e Políticas Públicas \\ Metodologia \\ Etapa 1 - Pesquisa de Dados Sobre Áreas Contaminadas no Brasil \\ Etapa 2 - Levantamento e Análise das Legislações Federais que Regem o Gerenciamento de Áreas Contaminadas no Brasil \\ Etapa 3 - Pesquisa a Respeito do Perfil da Indústria nos Estados \\ Etapa 4 - Análise dos Dados Levantados e Elaboração de um Panorama Sobre Áreas Contaminadas no Brasil \\ Resultado e Discussão \\ Conclusão \\ Referências
}

\begin{abstract}
RESUMO - Durante décadas, o solo foi utilizado como meio de disposição final de resíduos industriais e domésticos em virtude de seu suposto poder tampão e potencial de autodepuração, que permitiria sua recuperação sem o surgimento de grandes impactos. Considerado um receptor ilimitado para várias substâncias, uma infinidade de materiais foi descartado sem tratamento, em locais economicamente convenientes; isso porque questões econômicas sobrepunham-se às ambientais e havia, ainda, um desconhecimento dos impactos que esta disposição poderia causar, sem mencionar a ausência de legislação ambiental que regulasse tais questões. Somente na década de setenta, após a ocorrência de grandes casos de contaminação do ambiente e de pessoas, começaram a surgir legislações específicas que tratavam do tema. No Brasil, em 2009, foi publicada a CONAMA 420, que estabelece diretrizes para o gerenciamento de áreas contaminadas no país. O presente estudo tem como objetivo elaborar um panorama sobre o atendimento a CONAMA 420 por parte dos estados brasileiros, especificamente ao artigo 38 e seus incisos, frente ao perfil industrial de cada um deles. Como resultado verificou-se que a maioria dos estados não atende à norma, ou parte dela, e é possível inferir que não há ações efetivas, por parte do poder público, para a gestão dessas áreas contaminadas.
\end{abstract}

Palavras-chave: áreas contaminadas; solo; gerenciamento.

ABSTRACT - Over de last decades, the soil was used as a final disposal medium for industrial and domestic waste due to its supposed buffer power and self-purification potencial, which would allow its recovery without appearancement of major impacts. The soil was considered an unlimited container for many substances and a multitude of materials were discarded in economically viable sites; this was because economic issues overcame the environmental ones and there was also an ignorance of the impacts that this provision could cause, not to mention the absence of environmental legislation that regulated such issues. Only in the 1970s, after major cases of environment and people contamination, specific legislation began to emerge that addressed the issue. In 2009 it was published in Brasil the CONAMA 420, which establishes guidelines for the management of contaminated areas in the country. The present study has the objective of elaborating an overview of enforcement CONAMA 420 by the Brazilian states, specifically article 38 and its sections, as opposed to the industrial profile of each one of them. As a result, it was detected that most states do not comply with the law, or part of it, it is possible to infer that there is no effective action by the public power to manage these contaminated areas.

Keywords: contaminated areas; soil; management.

\section{INTRODUÇÃO}

O desenvolvimento industrial trouxe consigo um imenso passivo: a contaminação do meio ambiente por substâncias nocivas. Durante décadas, o solo e a água foram utilizados como meios de disposição final de resíduos industriais e domésticos. Independentemente de sua toxicidade, os resíduos eram descartados sem tratamento, em locais economicamente convenientes ou ecossistemas intactos (como rios, solos e áreas virgens), pois questões econômicas sobrepujavam as ambientais (Moeri et al., 2007). Além disso, havia ainda um desconhecimento dos graves impactos que compostos químicos poderiam causar ao ambiente e aos seres vivos, sem mencionar a total ausência de uma legislação ambiental que regulasse tais questões (CETESB, 1999).

A liberação indevida de substâncias perigosas no ambiente causou contaminação das águas superficiais e subterrâneas, bem como do solo (Lepsch, 2011). Gerou, ainda, riscos significativos à saúde humana, como no caso dos metais pesados contidos em resíduos industriais (Panagos et al., 2013). 
De acordo com CETESB (1999), durante décadas o solo foi considerado um receptor ilimitado de substâncias nocivas, em virtude de seu suposto "poder tampão e potencial de autodepuração", que permitiria sua recuperação sem o surgimento de grandes impactos para o meio. Entretanto este uso, aliado a outros, como por exemplo, o uso indiscriminado e descarte indevido de substâncias perigosas, levaram a uma série de problemas graves, como catástrofes ecológicas e contaminação de pessoas, animais, e do ambiente (Policarpo, 2008).

Com o passar do tempo, a indústria e os governos perceberam que havia a necessidade de mudança com relação às práticas ambientais. Os governos começaram, então, a criar legislações específicas para a área ambiental, e as indústrias começaram a introduzir políticas ambientais em seu sistema de gestão a fim de cumprir com as novas exigências legais e, principalmente, porque perceberam que incidentes e acidentes ambientais poderiam afetar até mesmo sua existência (Moeri et al., 2007).

Após a ocorrência de casos como Love Canal, na cidade Niagara Falls no estado de Nova York, e Lekkerkirk situada nas proximidades de Hoterdan na Holanda, os Estados Unidos e Europa criaram legislações específicas para regulamentarem temas como: o gerenciamento de resíduos sólidos, o uso de produtos químicos, o atendimento a emergências, entre outros, além do estabelecimento de normas que norteiam o processo de gerenciamento de áreas contaminadas (EEA, 2014 e EPA, 2017).

No Brasil, no mesmo período, foram elaboradas legislações que tratam sobre temas ambientais, como por exemplo, gestão de resíduos sólidos, proteção e manejo de áreas de florestas, e algumas relacionadas à questão dos solos; entretanto, tais legislações lidavam de forma marginal à respeito de áreas contaminadas, como afirma o documento do IPT (2016).

Em 1999, o Estado de São Paulo, através da Companhia Ambiental do Estado - CETESB, responsável pelas ações de controle de poluição no Estado, elaborou, um manual para gerenciamento de áreas contaminadas com a finalidade de regulamentar medidas e ações que possibilitassem o conhecimento das características da contaminação, os impactos por elas causados, além de subsidiar informações necessárias à tomada de decisão quanto ao tipo de intervenção mais adequado, de forma a minimizar riscos a que estão sujeitos a população, além do reestabelecimento da área para um uso previamente determinado (CETESB, 1999).

Somente no ano 2000 é que o Conselho Nacional do Meio Ambiente (CONAMA) aprovou a primeira norma federal que trata sobre o tema, a Resolução CONAMA $n^{\circ}$ 273, que dispõe diretrizes para o licenciamento ambiental de postos de combustíveis e sobre a prevenção e controle da poluição, por se tratar de empreendimentos com grande potencial poluidor dos diversos compartimentos ambientais, ou seja, solo, água, ar (CONAMA 273).

Em 2009, o governo federal, através do Conselho Nacional do Meio Ambiente publicou a resolução CONAMA $n^{\circ}$ 420, que trata especificamente sobre áreas contaminadas e dispõe sobre valores orientadores de qualidade do solo, além de estabelecer diretrizes para o gerenciamento ambiental de áreas contaminadas. Tal resolução dispõe, também, entre outras diretivas, sobre a criação do BDNAC, Banco de Dados Nacional sobre Áreas Contaminadas, com a finalidade de publicar informações sobre áreas contaminadas e suas características, através dos dados disponibilizados pelos órgãos e entidades estaduais de meio ambiente (CONAMA 420).

Algumas considerações são feitas às normas estabelecidas para gerenciamento de áreas contaminadas. De acordo com Riyis et al. (2017) nem sempre os procedimentos estabelecidos são suficientes para a realização de um diagnóstico preciso, uma vez que possibilitam o uso de tecnologias, métodos e abordagens inadequadas para realização do mapeamento da contaminação; assim como, em muitos casos não propiciam o conhecimento da interação do contaminante com o meio físico e não possibilitam subsidiar a avaliação de risco. Outro ponto levantado pelos mesmos autores, é que, em muitos casos, as etapas de investigação da área são negligenciadas, seja em função de fatores financeiros, ou por deficiência de planejamento, ou por desconhecimento.

Passados, nove anos da publicação da Resolução CONAMA $n^{\circ} 420$, nota-se que a grande maioria dos estados brasileiros tem dificuldades em cumprir com a mesma, ou com parte dela. Apenas, os estados de Minas gerais, Rio de Janeiro e São Paulo, possuem nos portais dos respectivos órgãos ambientais informações relevantes sobre o tema. 
O presente trabalho tem por objetivo avaliar o cumprimento da Resolução CONAMA 420, especificamente quanto ao artigo 38, seus parágrafos e incisos, que tratam da obrigatoriedade, por parte dos órgãos ambientais estaduais de "dar publicidade principalmente em seus portais institucionais na rede mundial de computadores, às informações sobre áreas contaminadas identificadas e suas principais características”, e contrastar com o nível de industrialização destas localidades, uma vez que após busca de dados disponibilizados, ficou constatado que as atividades industriais são a segunda maior causa das contaminações.

\section{ORIGEM DAS ÁREAS CONTAMINADAS}

Segundo CETESB (2016), no passado, a origem das áreas contaminadas se deveu ao desconhecimento e à falta de procedimentos seguros para o manejo de substâncias perigosas, ao desrespeito a esses procedimentos; ao armazenamento, manipulação e transporte inadequado de matérias-primas e produtos; à ocorrência de acidentes e vazamentos de produtos e substâncias.

Para Morinaga (2013), a ausência de controles sobre as fontes poluidoras viabilizou o surgimento de diversas contaminações, que por sua vez, geraram uma série de problemas, como danos à saúde e ao meio ambiente, restrições ao uso e ocupação do solo, além de danos ao patrimônio público e privado, com a desvalorização das propriedades.

Segundo o Relatório da EPA - United States Environmental Protection Agency sobre o Meio Ambiente (ROE, 2017), a contaminação do solo é consequência de uma série de atividades humanas e naturais, dentre elas, uso e manuseio de substâncias perigosas, atividades de mineração, descarte inadequado de resíduos, acidentes ambientais, descarte ilegal de efluente, uso de fertilizantes e pesticidas, vazamentos de tanques, além de atividades relacionadas à defesa nacional, furações, inundações.

Para a European Environment Agency - EEA (2000), o surgimento de áreas contaminadas está intimamente relacionado ao desenvolvimento de uma sociedade industrial orientada ao consumo. A contaminação do solo se deve a uma série de atividades humanas, principalmente a eliminação inadequada de resíduos, ao consumo exacerbado de produtos e o consequente desperdício destes, além do uso extensivo e manuseio de inúmeras substâncias perigosas, principalmente em processos industriais. Ainda segundo a EEA (2000), dificilmente em processos industriais há ou haverá - a exclusão da possibilidade de contaminação do solo e da água.

\section{NORMAS, LEGISLAÇÕES E POLITICAS PÚBLICAS}

Documentos da CETESB (1999) indicam que o conceito para proteção dos solos foi o último a ser abordado nas políticas ambientais dos países industrializados após problemas ambientais decorrentes da poluição das águas e da atmosfera ter sido tematizados e tratados.

O Brasil conta durante os últimos anos com leis que tratam de temas ambientais relacionados à questão dos solos; entretanto, tais legislações lidam de forma marginal sobre áreas contaminadas, como afirma o documento do IPT (2016). Por exemplo:

Decreto-Lei $\mathrm{n}^{0} 1.413$, de 14 de agosto de 1975, que dispõe sobre o controle da poluição do meio ambiente provocada por atividades industriais.

Lei Federal ${ }^{\circ}$ 6.938, de 31 de agosto de 1981, que dispõe sobre a Política Nacional do Meio Ambiente, seus fins e mecanismos de formulação e aplicação, e dá outras providências.

Lei Federal $n^{\circ}$ 9.605, de 12 de fevereiro de
1998, que dispõe sobre as sanções penais e administrativas derivadas de condutas e atividades lesivas ao meio ambiente, e dá outras providências.

Nos anos de 2000 e 2009 o Conselho Nacional do Meio Ambiente (CONAMA), aprovou duas resoluções, 273 e 420 respectivamente, que tratam da questão de contaminação de solo, sendo que a primeira dispõe de diretrizes para realização de licenciamento de postos de combustíveis e sobre a prevenção e controle da poluição, e a segunda estabelece, entre outras diretrizes, procedimentos para o gerenciamento ambiental de áreas contaminadas e a criação do BDNAC, Banco de Dados Nacional sobre Áreas Contaminadas (CONAMA 273 e 420).

A Associação Brasileira de Normas Técnicas - ABNT (2017) possui uma coleção de documentos técnicos que normatizam o procedimento de investigação de áreas contaminadas. São eles: NBR 15515-1:2007 
Versão Corrigida: 2011 - Passivo ambiental em solo e água subterrânea Parte 1: Avaliação preliminar; NBR 15515-2:2011 - Passivo ambiental em solo e água subterrânea Parte 2: Investigação confirmatória; NBR 15515-3:2013 - Avaliação de passivo ambiental em solo e água subterrânea Parte 3 - Investigação detalhada; NBR 16209:2013 - Avaliação de risco a saúde humana para fins de gerenciamento de áreas contaminadas; NBR 16210:2013 - Modelo conceitual no gerenciamento de áreas contaminadas - Procedimento e NBR 16435:2015 - Controle da qualidade na amostragem para fins de investigação de áreas contaminadas - Procedimento.

Em paralelo, alguns estados elaboraram normas e legislações específicas relacionadas a meio ambiente e a gestão de áreas contaminadas (IPT, 2016). No Estado de São Paulo, uma série de legislações de viés ambiental foi criada, dentre elas: Lei 997 de 31 de maio de 1976, dispõe sobre o controle da poluição do meio ambiente e Decreto ${ }^{\circ} 8468$ de 8 de setembro de 1976, que aprova o regulamento da Lei $n .^{\circ}$ 997, de 31 de maio de 1976, que dispõe sobre a prevenção e o controle da poluição do meio ambiente.

No final da década de 1990, a Companhia Ambiental do Estado de São Paulo (CETESB) firmou acordo de cooperação técnica com o governo da Alemanha, por meio de sua Sociedade de Cooperação Técnica - Deutsche Gesellschaft für Technische Zusammenarbeit GTZ, para a capacitação de recursos humanos e desenvolvimento de ferramentas de gestão de áreas contaminadas, o que resultou, em 1999, na elaboração do Manual de Gerenciamento de Áreas Contaminadas, na criação de um cadastro com os dados destas áreas e na introdução de novos requisitos (CETESB, 1999).

Em 2006, a CETESB (2006) estabeleceu, através da Decisão da Diretoria ${ }^{0}$ 010-2006-C, de 26 de janeiro de 2006, a necessidade de realização de processo de licenciamento para postos e sistemas retalhistas de combustíveis.

A CETESB (2007) divulgou a Decisão da Diretoria $n^{0}$ 103/2007/C/E de 22 de junho de 2007, que aprova o novo procedimento para gerenciamento de áreas contaminadas e cria o grupo gestor de áreas críticas GAC, com a finalidade, dentre outras atividades, de elaboração das planilhas para avaliação de risco, revisão da lista de valores orientadores de intervenção, elaboração de Instruções Técnicas para Gerenciamento de Áreas Contaminadas.

Em 2009, o Estado de São Paulo aprovou a lei $\mathrm{n}^{0} 13.577$ de 08 de julho de 2009, que dispõe sobre diretrizes e procedimentos para a proteção da qualidade do solo e gerenciamento de áreas contaminadas, e dá outras providências correlatas. Posteriormente, esta Lei foi regulamentada pelo Decreto $\mathrm{n}^{\circ} 59.263 / 2013$. No mesmo ano, a CETESB divulga a Decisão da Diretoria $n^{0}$ 263/2009/P, de 20 de outubro de 2009, que estabelece roteiro para realização de processos de investigação detalhada e elaboração de plano de intervenção para postos e sistemas retalhistas de combustíveis.

Nos anos de 2014 e 2016, a CESTEB aprova, através das Decisões da Diretoria $n^{\circ}$ 045/2014/E/C de 20 de fevereiro de 2014 e DD $n^{\circ}$ 263/2009/P de 22 de novembro de 2016, os valores orientadores solos e águas subterrâneas no Estado de São Paulo e dá outras providências.

Em 07 de fevereiro de 2017, a CETESB divulga a Decisão da Diretoria $n^{\circ} 038$, que revisa o procedimento de gerenciamento de áreas contaminadas, e dispõe sobre a aprovação do "Procedimento para a Proteção da Qualidade do Solo e das Águas Subterrâneas”, e estabelece "Diretrizes para Gerenciamento de Áreas Contaminadas no Âmbito do Licenciamento Ambiental”.

\section{METODOLOGIA}

Para o desenvolvimento deste trabalho foram percorridas as etapas a seguir.

\section{Etapa 1 - Pesquisa de Dados Sobre Áreas Contaminadas no Brasil}

As informações sobre áreas contaminadas foram obtidas dos sites dos órgãos ambientais dos 26 estados brasileiros, assim como do Distrito Federal, além do site do IBAMA. Apenas nos estados de São Paulo, Minas Gerais e Rio de Janeiro havia informações disponíveis sobre áreas contaminadas.

Na página do Instituto Brasileiro do Meio Ambiente e dos Recursos Naturais Renováveis IBAMA, especificamente no banco de áreas contaminadas BNDAC, é disponibilizado um breve resumo sobre o tema e links que remetem o usuário aos sites dos órgãos ambientais dos três estados que alimentam o banco: Estado de São Paulo - CETESB, Minas Gerais - FEAM e do Rio de Janeiro - INEA, que contêm informações 
detalhadas a respeito do tema.

Etapa 2 - Levantamento e Análise das Legislações Federais que Regem o Gerenciamento de Áreas Contaminadas no Brasil

Buscou-se levantar as legislações federais pertinentes ao tema, tanto no que diz respeito à proteção do solo, quanto ao Gerenciamento de Áreas Contaminadas. Dentre as legislações pesquisadas, foram avaliadas as diretrizes da CONAMA 420, primeira norma federal específica sobre áreas contaminadas (principalmente no que diz respeito à criação do Banco Nacional de Áreas Contaminadas BDNAC e as suas implicações) e aos artigos 37 e 38 que tratam da obrigatoriedade de divulgação e gestão de dados referentes a áreas contaminadas pelos órgãos ambientais dos Estados.

\section{Etapa 3 - Pesquisa a Respeito do Perfil da Indústria nos Estados}

Foram levantados dados referentes ao número de indústrias de cada estado, participação no PIB nacional e principais tipos de indústria estabelecidas em cada estado Brasileiro, com a finalidade de traçar um perfil da Indústria de cada uma destas localidades. Os dados foram obtidos através do Portal da Indústria (http://www.portaldaindustria.com.br).

Etapa 4 - Análise dos Dados Levantados e Elaboração de um Panorama Sobre Áreas Contaminadas no Brasil

Foram levantados dados referentes à origem das áreas contaminadas nos três estados brasileiros cujos dados estão disponíveis para consulta, ou seja, estados de São Paulo, Minas Gerais e Rio de Janeiro; além de informações a respeito da distribuição geográfica dessas áreas contaminadas pelos Estados.

Foram comparados os dados disponíveis nos Portais ambientais com os dados obtidos no Portal da Indústria, para elaboração de um panorama sobre o atendimento a Resolução CONAMA número 420.

\section{RESULTADOS E DISCUSSÃO}

O Banco de Dados Nacional sobre Áreas Contaminadas (BDNAC) foi instituído pela Resolução CONAMA n. ${ }^{\circ} 420$ de 30 de dezembro de 2009, com a finalidade tornar públicas informações sobre áreas contaminadas no País, a partir de dados disponibilizados pelos órgãos ambientais estaduais. Entretanto, segundo o IPT (2016) e o IBAMA (2017), o BDNAC contém informações de apenas três Estados: São Paulo, Rio de Janeiro e Minas Gerais.

O IPT (2016) divulgou em seu relatório Panorama GAC Mapeamento da Cadeia de Gerenciamento de Áreas Contaminadas um levantamento de áreas contaminadas de todo o país (conforme a figura 1). Segundo o relatório, as informações foram obtidas através da aplicação de questionário enviado a todos os órgãos ambientais dos estados brasileiros, e nos casos onde não houve retorno das informações, o levantamento foi feito através de consulta a referências bibliográficas variadas, como artigos técnicos e notícias na internet.

Dentre os estados da federação, São Paulo possui cerca de $80 \%$ das áreas contaminadas cadastradas (IPT, 2016).

Segundo a CETESB, (2016), em maio de 2002, haviam 255 áreas contaminadas registradas no Estado de São Paulo. Após a última atualização, em dezembro de 2016, foram totalizados 5.662 registros no Cadastro de Áreas Contaminadas e Reabilitadas no Estado de São Paulo e de acordo com a figura 2, as áreas contaminadas no estado concentram-se em sua maioria na cidade de São Paulo (2050 áreas), seguido pelo Interior Paulista (2263 áreas), região metropolitana de São Paulo (979), e Litoral (370) (CETESB, 2016).

A CETESB (2016) afirma ainda que o aumento do número de áreas cadastradas é devido aos processos de licenciamento de postos de combustíveis e outras fontes como: indústria, comércio, tratamento e disposição de resíduos, além de atendimento a acidentes e de atividades de fiscalização realizadas pelo órgão.

Das regiões contaminadas no Estado, 73,06\% se originaram de atividades de postos de combustíveis, $17,70 \%$ em indústrias, 5,29\% em atividades comerciais, 3,00\% em atividades relacionas a resíduos e $0,95 \%$ tiveram sua origem em virtude de acidentes ou agricultura ou origem desconhecida conforme a figura 3.

No Estado do Rio de Janeiro, o Instituto Estadual do Ambiente - INEA (2017) afirma que algumas áreas contaminadas foram ou estão sendo investigadas e remediadas. Entretanto, a quantidade de áreas contaminadas no Estado é um problema de dimensões ainda não mensuradas. 
Segundo o INEA, no último levantamento realizado em 2015, existiam 328 áreas que fazem parte do cadastro de áreas contaminadas do Estado, que se originaram principalmente de atividades relacionadas a postos de combustíveis (59\%), seguido por atividades industriais (34\%), transportes (5\%) e áreas de disposição de resíduos (3\%), conforme demonstrado na figura 4.
Estas áreas estão distribuídas pelo Estado do Rio de Janeiro, sendo que cerca de 38\% (126 áreas) estão situadas na capital fluminense, 34\% (110 áreas) estão distribuídas pelas 20 cidades que compõem a região metropolitana do Rio de Janeiro, 25\% (81 áreas) se localizam no interior do estado e 3\% (11 áreas) no litoral do estado, como pode ser verificado na figura 5 .

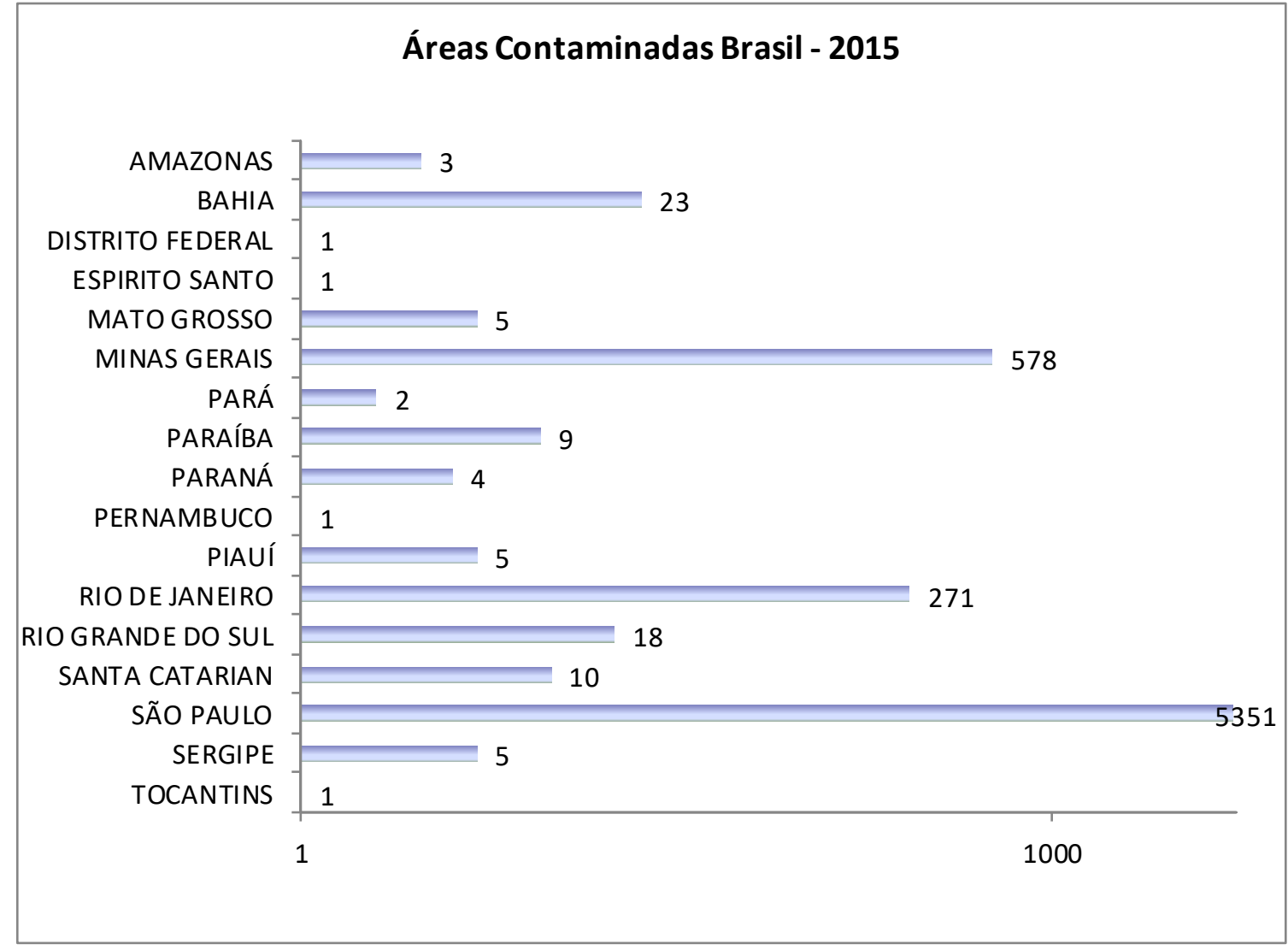

Figura 1 - Distribuição das áreas contaminadas no Brasil no ano de 2015 (Fonte: adaptado de IPT, 2016 (p.67).

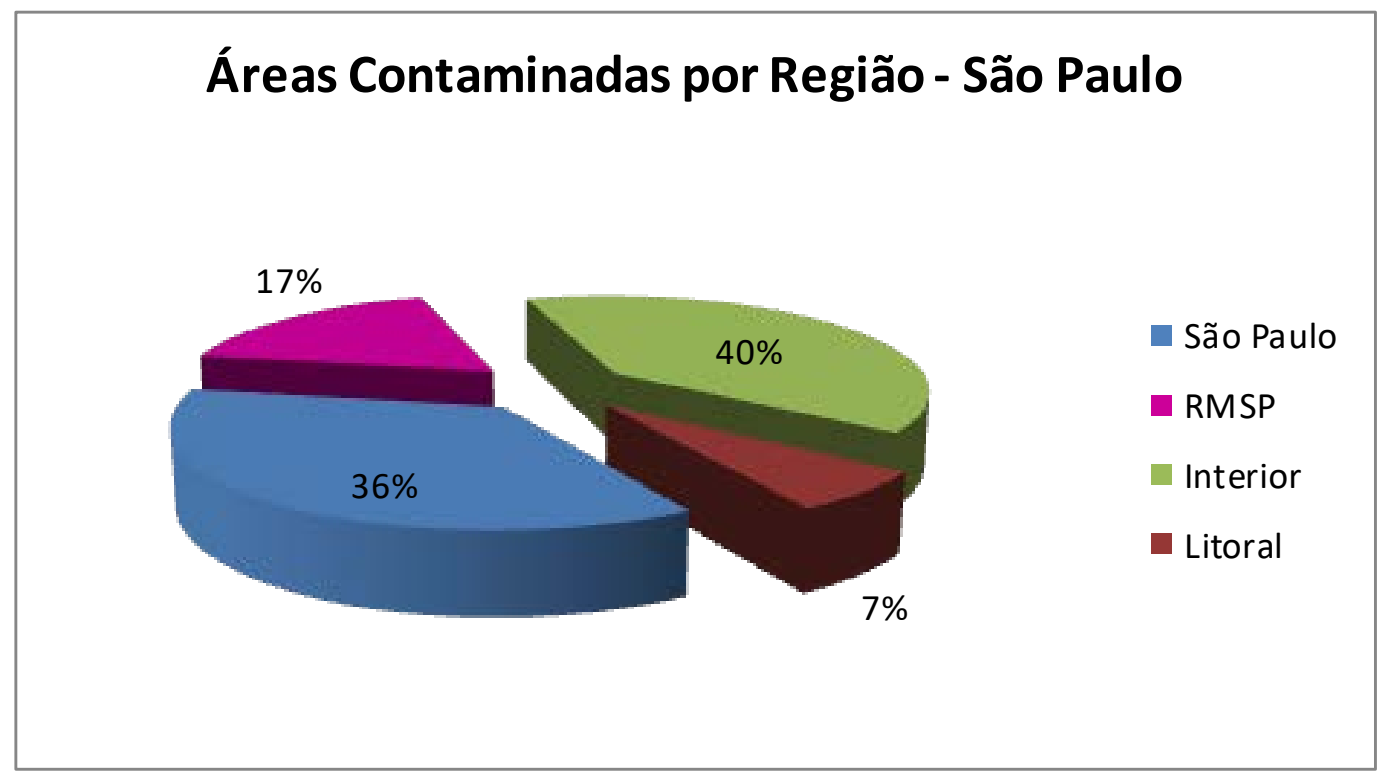

Figura 2 - Distribuição das áreas contaminadas no Estado de São Paulo segundo sua localização (Fonte: adaptado de CETESB, 2016). 


\section{Origem das Áreas Contamindas - São Paulo}

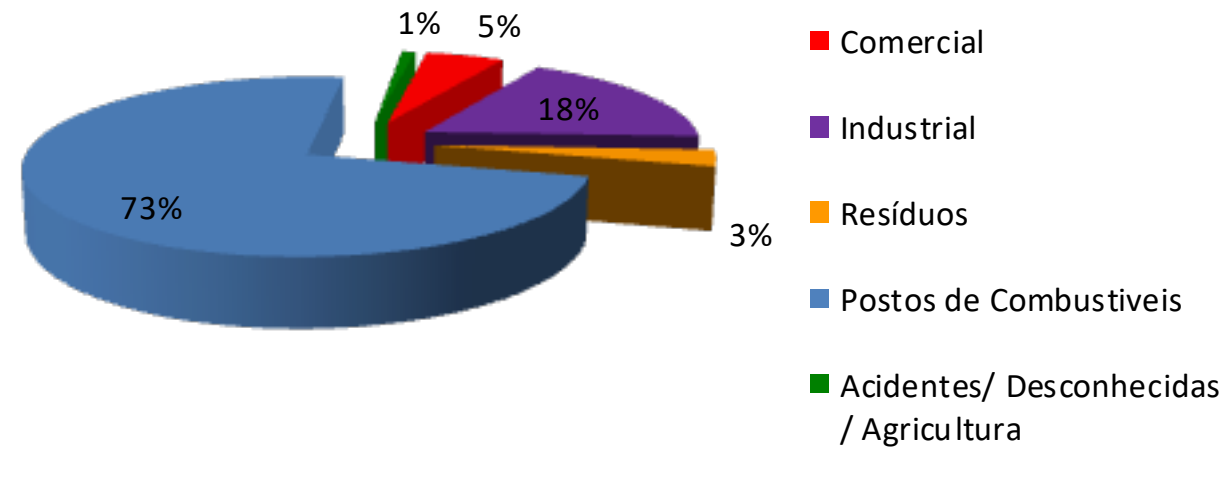

Figura 3 - Distribuição de áreas contaminadas de acordo com a atividade de origem no Estado de São Paulo (Fonte: adaptado de CETESB, 2016).

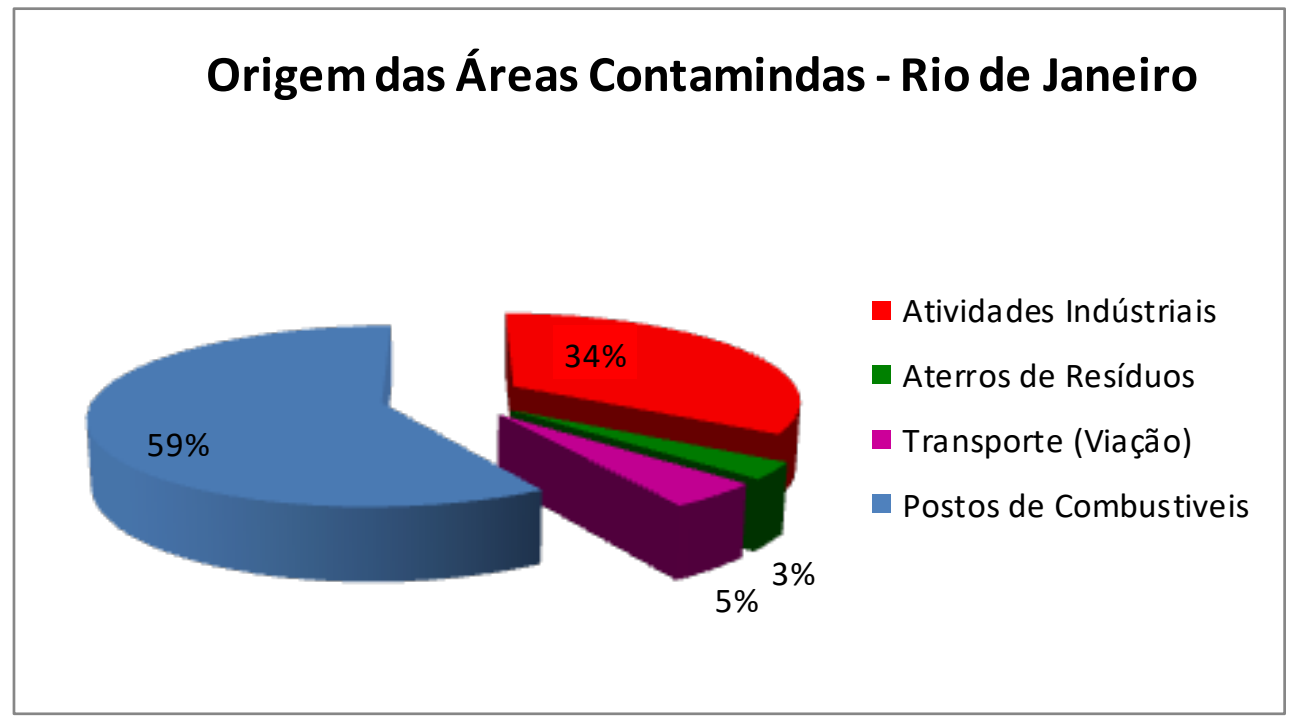

Figura 4 - Distribuição de áreas contaminadas de acordo com a atividade de origem no Estado do Rio de Janeiro (Fonte: adaptado de INEA, 2016).

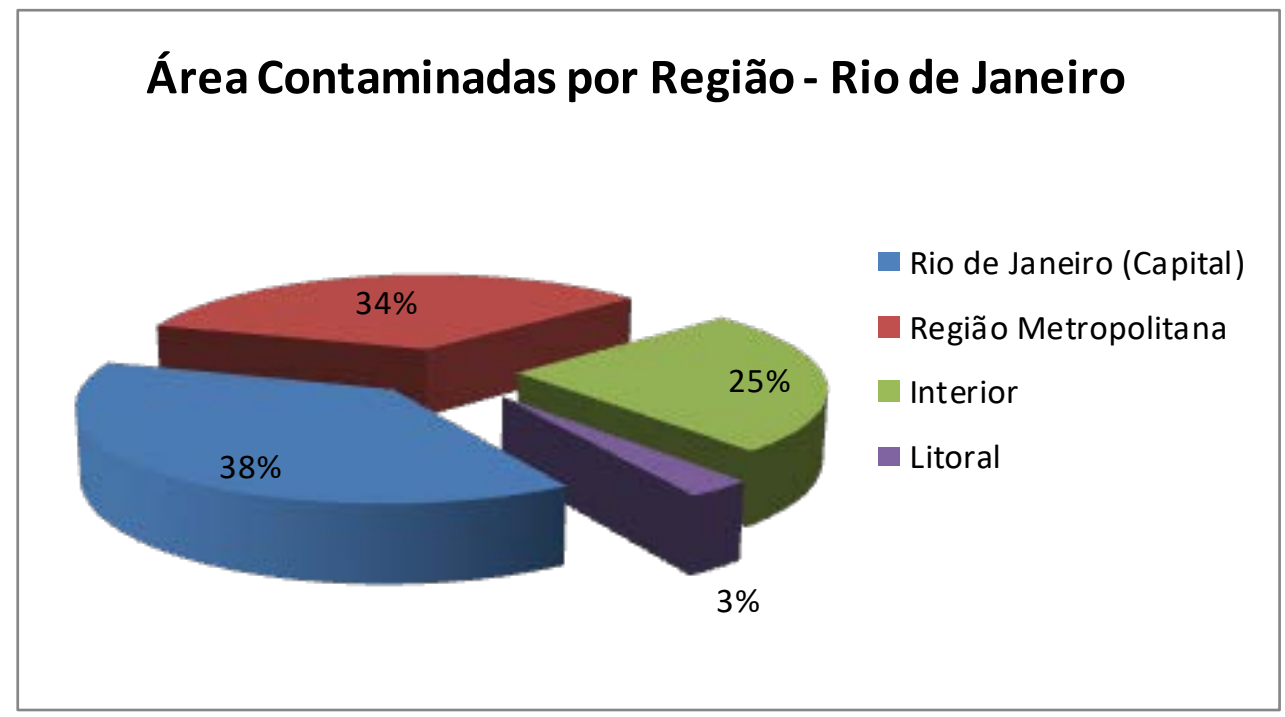

Figura 5 - Distribuição das áreas contaminadas no Estado do Rio de Janeiro segundo sua localização (Fonte: adaptado de INEA, 2016). 
No Estado de Minas Gerais, a Fundação Estadual do Meio Ambiente - FEAM (2016) mantém desde 2007 um banco de dados com informações sobre áreas contaminadas.

As informações são oriundas de áreas declaradas no banco de declarações ambientais de áreas identificadas no âmbito do Sistema Estadual do Meio Ambiente - Sisema, ou em virtude de denúncias, atendimento a emergência, processos de licenciamento nos quais houve suspeitas da existência de uma possível contaminação.

Até o ano de 2016, foram registradas 642 áreas contaminadas e reabilitadas no Estado de Minas Gerais. Segundo a FEAM, as áreas contaminadas e reabilitadas cadastradas distribuem-se por 170 municípios do Estado, sendo que 202 áreas estão localizadas na capital Belo Horizonte, 131 estão situadas entre os 33 municípios pertencentes à região metropolita e o restante das áreas contaminadas do Estado (309) estão localizadas no interior do Estado, conforme a figura 6 (FEAM, 2016).

Assim como no Estado de São Paulo, nota-se na figura 7 que o maior número de áreas contaminadas no Estado de Minas Gerais é oriundo de atividades de postos revendedores de combustíveis (74\%), seguida por atividades industriais (12\%), transporte ferroviário (7\%), refino de petróleo (3\%), atividades de mineração (2\%) e base de combustíveis (2\%) (FEAM, 2016).

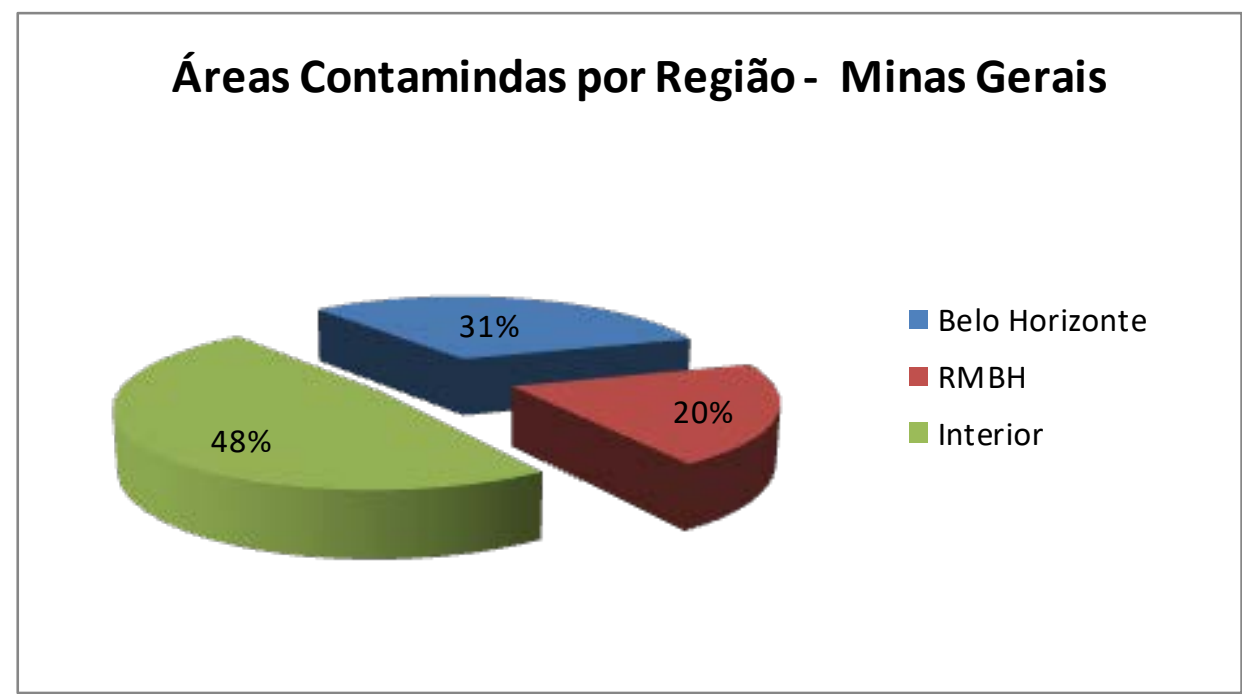

Figura 6 - Distribuição das áreas contaminadas no Estado de Minas Gerais segundo sua localização (Fonte: adaptado de FEAM, 2016).

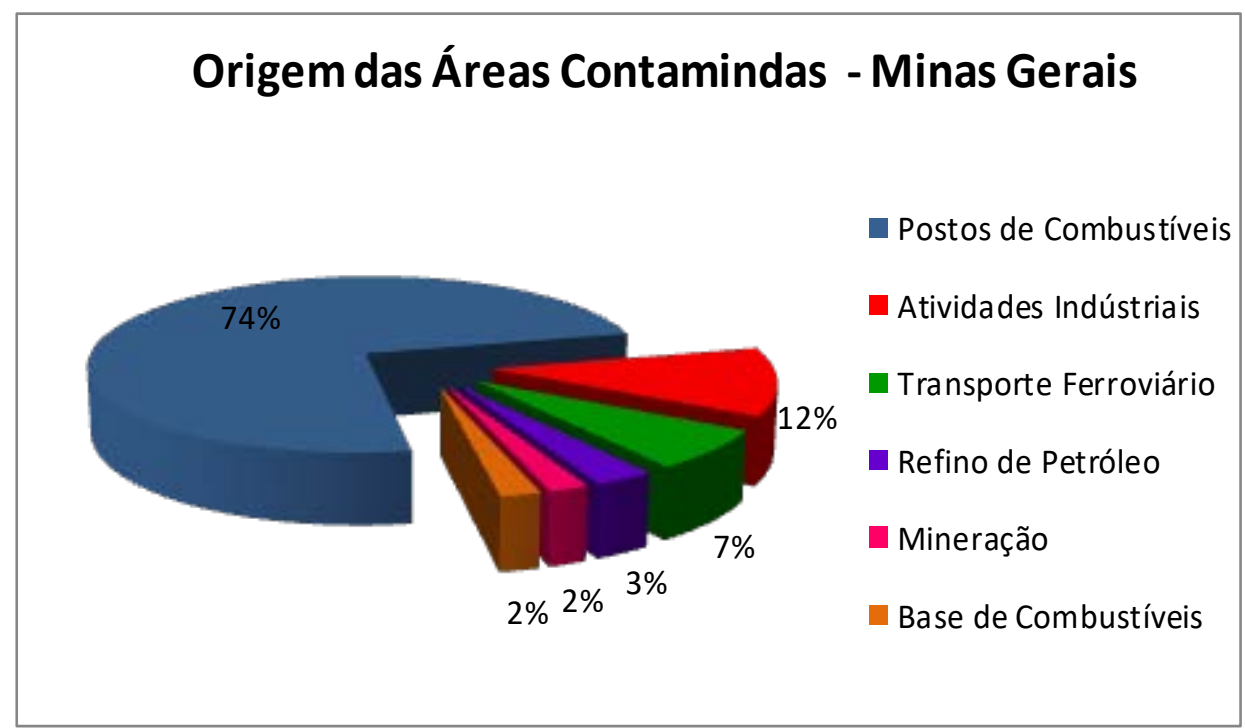

Figura 7 - Distribuição de áreas contaminadas de acordo com a atividade de origem (Fonte: adaptado de FEAM, 2016).

Além da criação do BDNAC a resolução CONAMA 420, estabelece os critérios para gerenciamento de áreas contaminadas, e dentre eles, prevê em seu artigo 38, que:

Os órgãos ambientais competentes, observando o sigilo necessário, previsto em lei, 
deverão dar publicidade principalmente em seus portais institucionais na rede mundial de computadores, às informações sobre áreas contaminadas identificadas e suas principais características na forma de um relatório que deverá conter no mínimo:

I - a identificação da área com dados relativos à toponímia e georreferenciamento, características hidrogeológicas, hidrológicas e fisiografia;

II - a(s) atividade(s) poluidora(s) ativa(s) e inativa(s), fonte poluidora primária e secundária ou potencial, extensão da área afetada, causa da contaminação (acidentes, vazamentos, disposição inapropriada do produto químico ou perigoso, dentre outros);

III - as características das fontes poluidoras no que se refere à disposição de resíduos, armazenamento de produtos químicos e perigosos, produção industrial, vias de contaminação e impermeabilização da área;

IV - a classificação da área em AI, ACI, AMR e AR;

$\mathrm{V}$ - o uso atual do solo da área e seu entorno, ação em curso e pretérita;

VI - os meios afetados e concentrações de contaminantes;

VII - a descrição dos bens a proteger e distância da fonte poluidora;

VIII - os cenários de risco e rotas de exposição;

IX - as formas de intervenção; e

$X$ - as áreas contaminadas críticas. (CONAMA 420).

Segundo o IBAMA (2017), nenhum dos estados da federação disponibiliza informações completas exigidas no artigo 38 da resolução CONAMA 420, conforme tabela 1 abaixo.

Tabela 1 - Tipo de dados sobre áreas contaminadas que são disponibilizados por unidade da federação.

\begin{tabular}{|c|c|c|c|c|c|c|c|c|c|c|c|c|c|c|c|c|c|c|c|c|c|c|c|c|c|c|c|c|}
\hline & Dados & $\mathrm{AC}$ & AL & AP & $\mathrm{AM}$ & BA & $\mathrm{CE}$ & DF & ES & GO & MA & MT & MS & MG & PA & PB & PR & $\mathrm{PE}$ & PI & $\mathrm{RJ}$ & $\mathrm{RN}$ & RS & $\mathrm{RO}$ & RR & $\mathrm{SC}$ & SP & SE & TO \\
\hline 1 & Identificação das áreas & - & - & - & - & - & - & - & - & - & - & - & - & - & - & - & - & - & - & - & - & - & - & - & - & - & - & - \\
\hline 1.1 & Toponímia & - & - & - & - & - & - & - & - & - & - & - & - & $\bullet$ & - & - & - & - & - & $\bullet$ & - & - & - & - & - & - & - & - \\
\hline 1.2 & Georreferenciamento & - & - & - & - & - & - & - & - & - & - & - & - & - & - & - & - & - & - & - & - & - & - & - & - & - & - & - \\
\hline 1.3 & $\begin{array}{l}\text { Características } \\
\text { hidrogeológicas, } \\
\text { hidrológicas e fisiografia }\end{array}$ & - & - & - & - & - & - & - & - & - & - & - & - & - & - & - & - & - & - & - & - & - & - & - & - & - & - & - \\
\hline 2 & Atividades poluidoras & - & - & - & - & - & - & - & - & - & - & - & - & - & - & - & - & - & - & - & - & - & - & - & - & - & - & - \\
\hline 2.1 & Ativas e inativas & - & - & - & - & - & - & - & - & - & - & - & - & $\bullet$ & - & - & - & - & - & $\bullet$ & - & - & - & - & - & $\bullet$ & - & - \\
\hline 2.2 & $\begin{array}{l}\text { Fonte poluidora primária e } \\
\text { secundária ou potencial }\end{array}$ & - & - & - & - & - & - & - & - & - & - & - & - & $\bullet$ & - & - & - & - & - & $\bullet$ & - & - & - & - & - & $\bullet$ & - & - \\
\hline 2.3 & Extensão de área afetada & - & - & - & - & - & - & - & - & - & - & - & - & - & - & - & - & - & - & - & - & - & - & - & - & - & - & - \\
\hline 2.4 & Causa da contaminação & - & - & - & - & - & - & - & - & - & - & - & - & - & - & - & - & - & - & - & - & - & - & - & - & - & - & - \\
\hline 3 & $\begin{array}{l}\text { Características das fontes } \\
\text { poluidoras no que se } \\
\text { refere à disposição de } \\
\text { resíduos, armazenamento } \\
\text { de produtos industrial, } \\
\text { vias de contaminação e } \\
\text { impermeabilização da área }\end{array}$ & - & - & - & - & - & - & - & - & - & - & - & - & - & - & - & - & - & - & - & - & - & - & - & - & - & - & - \\
\hline 4 & Classificação das áreas & - & - & - & - & - & - & - & - & - & - & - & - & - & - & - & - & - & - & - & - & - & - & - & - & - & - & - \\
\hline 4.1 & $\begin{array}{l}\text { Tipologia AI, ACI, AMR } \\
\text { e AR }\end{array}$ & - & - & - & - & - & - & - & - & - & - & - & - & • & - & - & - & - & - & • & - & - & - & - & - & $\bullet$ & - & - \\
\hline 4.2 & Identificação de fase livre & - & - & - & - & - & - & - & - & - & - & - & - & - & - & - & - & - & - & • & - & - & - & - & - & • & - & - \\
\hline 4.3 & $\begin{array}{l}\text { Situação de remediação } \\
\text { de fase livre }\end{array}$ & - & - & - & - & - & - & - & - & - & - & - & - & $\bullet$ & - & - & - & - & - & $\bullet$ & - & - & - & - & - & $\bullet$ & - & - \\
\hline 5 & Uso atual & - & - & - & - & - & - & - & - & - & - & - & - & - & - & - & - & - & - & - & - & - & - & - & - & - & - & - \\
\hline 5.1 & Da área & - & - & - & - & - & - & - & - & - & - & - & - & - & - & - & - & - & - & $\bullet$ & - & - & - & - & - & - & - & - \\
\hline 5.2 & Do entorno & - & - & - & - & - & - & - & - & - & - & - & - & - & - & - & - & - & - & - & - & - & - & - & - & - & - & - \\
\hline 5.3 & Ação em curso & - & - & - & - & - & - & - & - & - & - & - & - & $\bullet$ & - & - & - & - & - & • & - & - & - & - & - & - & - & - \\
\hline 5.4 & Ação pretérita & - & - & - & - & - & - & - & - & - & - & - & - & - & - & - & - & - & - & - & - & - & - & - & - & - & - & - \\
\hline 6 & $\begin{array}{l}\text { Meios afetados e } \\
\text { contaminantes }\end{array}$ & - & - & - & - & - & - & - & - & - & - & - & - & - & - & - & - & - & - & - & - & - & - & - & - & - & - & - \\
\hline 6.1 & Meios afetados & - & - & - & - & - & - & - & - & - & - & - & - & $\bullet$ & - & - & - & - & - & $\bullet$ & - & - & - & - & - & $\bullet$ & - & - \\
\hline 6.2 & Contaminantes & - & - & - & - & - & - & - & - & - & - & - & - & - & - & - & - & - & - & - & - & - & - & - & - & - & - & - \\
\hline 6.2 .1 & Por elemento químico & - & - & - & - & - & - & - & - & - & - & - & - & $\bullet$ & - & - & - & - & - & - & - & - & - & - & - & - & - & - \\
\hline 6.2 .2 & Por agrupamentos & - & - & - & - & - & - & - & - & - & - & - & - & - & - & - & - & - & - & $\bullet$ & - & - & - & - & - & $\bullet$ & - & - \\
\hline 6.3 & $\begin{array}{l}\text { Concentração de } \\
\text { contaminantes }\end{array}$ & - & - & - & - & - & - & - & - & - & - & - & - & - & - & - & - & - & - & - & - & - & - & - & - & - & - & - \\
\hline 7 & $\begin{array}{l}\text { Descrição dos bens a } \\
\text { proteger e distância da } \\
\text { fonte poluidora }\end{array}$ & - & - & - & - & - & - & - & - & - & - & - & - & - & - & - & - & - & - & - & - & - & - & - & - & - & - & - \\
\hline 8 & $\begin{array}{l}\text { Cenários de risco e rotas } \\
\text { de exposição }\end{array}$ & - & - & - & - & - & - & - & - & - & - & - & - & - & - & - & - & - & - & - & - & - & - & - & - & - & - & - \\
\hline 9 & Formas de intervenção & - & - & - & - & - & - & - & - & - & - & - & - & - & - & - & - & - & - & • & - & - & - & - & - & $\bullet$ & - & - \\
\hline 10 & $\begin{array}{l}\text { Áreas contaminadas } \\
\text { críticas }\end{array}$ & - & - & & - & & - & - & 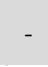 & - & - & - & - & - & - & - & - & - & - & - & - & - & - & - & - & $\bullet$ & - & - \\
\hline
\end{tabular}

Fonte: Adaptado de IBAMA (2017). 
Tratando-se dos três portais que alimentam o BDNAC, no site da CETESB e a da FEAM encontram-se divulgadas séries históricas iniciada em 2002 e 2007, respectivamente, até o ano de 2016, com dados referentes às contaminações. São disponibilizados também relatórios com a sistematização dos dados, além de mapas geográficos indicando os locais afetados. O INEA menciona que em 2013 realizou o lançamento da $1^{\text {a }}$ edição do cadastro de áreas contaminadas no Estado do Rio de Janeiro, atualizado em duas ocasiões: 2014 e 2015.

Os dados estão disponibilizados em forma de tabelas

Em levantamento realizado nos portais institucionais dos órgãos ambientais dos vinte e seis Estados brasileiros, além do Distrito Federal, nota-se que na grande maioria há pouca ou nenhuma estrutura estabelecida para identificar, mapear e gerenciar áreas contaminadas, e consequentemente cumprir com o artigo 38 da Resolução CONAMA 420.

A obtenção e divulgação de dados relacionados à existência destes locais não é priorizada pelos órgãos ambientais. Dos vinte e sete sites institucionais visitados, apenas nos Estados de Minas Gerais, Rio de Janeiro e São Paulo há informações sobre áreas contaminadas (conforme demonstra a tabela 2); na maioria dos portais, não há menção ao assunto. Além disso, o tema é citado marginalmente (em forma de notícia) em onze páginas, e em apenas dois Estados (Minas Gerais e São Paulo) há informações sobre legislações relacionadas ao tema.

Tabela 2 - Divulgação de dados sobre áreas contaminadas nos portais dos órgãos ambientais estaduais e número de indústrias por estado.

\begin{tabular}{|c|c|c|c|c|c|}
\hline ESTADO & $\begin{array}{c}\text { ORGÃO } \\
\text { AMBIENTAL } \\
\text { ESTADUAL }\end{array}$ & $\begin{array}{l}\mathrm{N}^{\circ} \text { de Áreas Contaminadas } \\
\text { divulgadas nos Portais } \\
\text { Institucionais dos Orgãos } \\
\text { Ambientais / Ano }\end{array}$ & $\begin{array}{c}\text { Divulgação de Área Contaminadas } \\
\text { no BDNAC }\end{array}$ & $\begin{array}{l}\text { Número de Áreas } \\
\text { Contaminadas } \\
\text { divulgadas pelo IPT - } \\
\text { Relatório Panorama } \\
\text { GAC - } 2014\end{array}$ & $\begin{array}{c}\text { Número de } \\
\text { Industrias } \\
\text { no Estado } \\
\text { em } 2016\end{array}$ \\
\hline Acre & IMAC & Não há informação & - & - & 941 \\
\hline Alagoas & IMA & Não há informação & - & - & 3095 \\
\hline Amapa & IMAP & Não há informação & - & - & 603 \\
\hline Amazonia & IPAAM & Não há informação & - & 3 & 2788 \\
\hline Bahia & INEMA & Não há informação & - & 23 & 17269 \\
\hline Ceara & SEMACE & Não há informação & - & - & 14438 \\
\hline Distrito Federal & IBRAM & Não há informação & - & 1 & 5530 \\
\hline Espirito Santo & IEMA & Não há informação & - & 1 & 10544 \\
\hline Goais & SECIMA & Não há informação & - & - & 17987 \\
\hline Maranhão & SEMA & Não há informação & - & - & 4306 \\
\hline Mato Grosso & SEMA & Não há informação & - & 5 & 8929 \\
\hline Mato Grosso do Sul & IMASUL & Não há informação & - & - & 5811 \\
\hline Minas Gerais & FEAM & 642 & Remete ao portal do orgão ambiental & 578 & 61070 \\
\hline Pará & SEMAS & Não há informação & - & 2 & 6614 \\
\hline Paraíba & SUDEMA & Não há informação & - & 9 & 6150 \\
\hline Paraná & IAP & Não há informação & - & 4 & 43557 \\
\hline Pernambuco & $\mathrm{CPRH}$ & Não há informação & - & 1 & 13671 \\
\hline Piauí & SEMAR & Não há informação & - & 5 & 3955 \\
\hline Rio de Janeiro & INEA & 328 & Remete ao portal do orgão ambiental & 271 & 24978 \\
\hline Rio Grande do Norte & IDEMA & Não há informação & - & - & 6257 \\
\hline Rio Grande do Sul & FEPAM & Não há informação & - & 18 & 48605 \\
\hline Rondônia & SEDAM & Não há informação & - & - & 3592 \\
\hline Roraima & FEMARH & Não há informação & - & - & 519 \\
\hline Santa Catarina & FATMA & Não há informação & - & 10 & 43282 \\
\hline São Paulo & CETESB & 5662 & Remete ao portal do orgão ambiental & 5351 & 127331 \\
\hline Sergipe & ADEMA & Não há informação & - & 5 & 3029 \\
\hline Tocantins & SEMARH & Não há informação & - & 1 & 2227 \\
\hline
\end{tabular}

Observadas as origens das contaminações do ambiente, mesmo com os poucos dados disponíveis no Brasil, verifica-se que atividades industriais são o segundo maior contribuinte em 
número de áreas contaminadas identificadas (gráficos 3, 4 e 7)

Segundo a Confederação Nacional da Indústria, no Brasil há 487.078 indústrias, destas $44 \%$ estão localizadas nos estados de Minas Gerais, Rio de Janeiro e São Paulo, onde é declarada a existência de 6.632 áreas contaminadas. As outras 273.699 indústrias, ou seja $66 \%$ do total, estão situadas nos outros estados da federação, cujos portais institucionais dos órgãos ambientais não indicam a existência de áreas contaminadas, como verificado na Tabela 2.

Entretanto, segundo o relatório Panorama GAC Mapeamento da Cadeia de Gerenciamento de Áreas Contaminadas no ano de 2015, há nestas localidades 88 áreas contaminadas.

Analisando-se a origem das áreas contaminadas declaradas no BDNAC (6.632 áreas contaminadas), para os estados de São Paulo, Rio de Janeiro e Minas Gerais, observa-se que cerca de 19\% do total (111 - Rio de Janeiro; 1.002 - São Paulo e 121 - Minas Gerais) originaram-se de atividades industriais. Considerando o número total de indústrias destes três estados (213. 379 indústrias, 24.978 - RJ; 127.331- SP e 61.070 - MG), e assumindo, hipoteticamente, que todas as áreas industriais dos três estados tenham sido investigadas e, observando que o total de áreas contaminadas originadas de atividades industriais é de 1.234 áreas contaminadas, tem-se que $0,6 \%$ do total de 213.379 indústrias estariam com suas áreas contaminadas. Ao se aplicar esse percentual para o restante do país, é possível inferir que todos os estados teriam áreas contaminadas cuja origem seriam atividades industriais, como indicado na tabela 3.

Tabela 3 - Número hipotético de áreas contaminadas nos estados

\begin{tabular}{|c|c|c|}
\hline ESTADO & $\begin{array}{l}\text { Número de Industrias no } \\
\text { Estado em } 2016\end{array}$ & $\begin{array}{c}\text { Número hipotético de } \\
\text { áreas contaminadas nos } \\
\text { Estados }\end{array}$ \\
\hline Acre & 941 & 5,646 \\
\hline Alagoas & 3095 & 18,57 \\
\hline Amapa & 603 & 3,618 \\
\hline Amazonia & 2788 & 16,728 \\
\hline Bahia & 17269 & 103,614 \\
\hline Ceara & 14438 & 86,628 \\
\hline Dis trito Federal & 5530 & 33,18 \\
\hline Espirito Santo & 10544 & 63,264 \\
\hline Goais & 17987 & 107,922 \\
\hline Maranhão & 4306 & 25,836 \\
\hline Mato Grosso & 8929 & 53,574 \\
\hline Mato Grosso do Sul & 5811 & 34,866 \\
\hline Pará & 6614 & 39,684 \\
\hline Paraíba & 6150 & 36,9 \\
\hline Paraná & 43557 & 261,342 \\
\hline Pernambuco & 13671 & 82,026 \\
\hline Piauí & 3955 & 23,73 \\
\hline Rio Grande do Norte & 6257 & 37,542 \\
\hline Rio Grande do Sul & 48605 & 291,63 \\
\hline Rondônia & 3592 & 21,552 \\
\hline Roraima & 519 & 3,114 \\
\hline Santa Catarina & 43282 & 259,692 \\
\hline Sergipe & 3029 & 18,174 \\
\hline Tocantins & 2227 & 13,362 \\
\hline Total & 273699 & 1642,194 \\
\hline
\end{tabular}


Diante deste cenário, teríamos no mínimo 2876 contaminadas no Brasil, oriundas de atividades industriais, distribuídas por todos estados. Destas, 1642 se quer foram identificadas, ou se foram não há informações disponíveis para a população interessada sobre estes locais.

Ao analisarmos a origem das áreas contaminadas declaradas pelos três estados que disponibilizam os dados, notamos que este cenário está subdimensionado, uma vez que existem diversas outra atividades comuns a qualquer localidade, e que podem ser fontes de contaminação, como é o caso por exemplo da disposição de resíduos.

Considerando legislações como Lei $\mathrm{n}^{\circ}$ 6.938, de 31 de agosto de 1981, que dispõe sobre a Política Nacional do Meio Ambiente, as resoluções CONAMA 273 e 420, estas áreas deveriam entre outros procedimentos, estar sofrendo processos de gerenciamentos de áreas contaminadas, cujo principal objetivo é reduzir, para níveis aceitáveis, os riscos a que estão sujeitos a população e o meio ambiente em decorrência de exposição às substâncias provenientes das áreas contaminadas.

\section{CONCLUSÕES}

Diante do panorama apresentado, pode-se concluir que o assunto "Áreas Contaminadas" vem sendo tratado no Brasil de maneira marginal. A questão só foi reconhecida no País após a ocorrência de casos graves de contaminação de pessoas e do meio, por volta dos anos 1970.

Diretrizes e legislações com a finalidade de regulamentar a gestão dessas áreas só foram elaboradas no final da década de noventa e, ainda hoje, a maioria dos estados da federação não cumprem com requisitos mínimos estabelecidos para a gestão de tais localidades como, por exemplo, a publicização de dados sobre a existência destas áreas.

A maioria dos órgãos ambientais dos Estados brasileiros não tem divulgado qualquer tipo de informação sobre o tema, assim como não foram encontradas disponíveis normas e legislação estaduais que tratem sobre o assunto. Apenas três
Estados (São Paulo, Minas Gerais e Rio de Janeiro) disponibilizam informações sobre a questão, sendo que em apenas dois (São Paulo e Minas Gerais) os dados estão compilados e analisados.

A ausência de normas e legislação sobre o assunto pode expor pessoas e o meio ambiente de forma significativa e irreversível, como alguns casos citados no trabalho.

Nos três Estados nos quais há informações, nota-se similaridade quanto à origem das atividades contaminantes, sendo que os postos revendedores de combustíveis, as atividades industriais, a disposição de resíduos e as atividades comerciais estão entre as mais encontradas. Atividades estas que ocorrem em todos os Estados e Municípios do País. Portanto, é possível inferir que não há, por parte do poder público, ações efetivas para a gestão dessas áreas contaminadas.

\section{REFERÊNCIAS}

ASSOCIAÇÃO BRASILEIRA DE NORMAS TÉCNICAS. 16435: Controle da qualidade na amostragem para fins de investigação de áreas contaminadas - Procedimento. Rio de Janeiro, 2015.

ASSOCIAÇÃO BRASILEIRA DE NORMAS TÉCNICAS. NBR15515-1:2007: Passivo Ambiental em solo e água subterrânea Parte 1: Avaliação Preliminar. Rio de Janeiro, 2007.

ASSOCIAÇÃO BRASILEIRA DE NORMAS TÉCNICAS. NBR16210: Modelo Conceitual no gerenciamento de áreas contaminadas - Procedimento. Rio de Janeiro, 2013.

ASSOCIAÇÃO BRASILEIRA DE NORMAS TÉCNICAS. Normas ABNT. Rio de Janeiro, 2017. Disp. em: $<$ http://abntcatalogo.com.br/normagrid.aspx>. Acesso em 13 de ago. 2017.

BRASIL, Ministério do Meio Ambiente. Banco de Dados Nacional sobre Áreas Contaminadas. Brasília, DF, abr 2017. Disponível em:< http://www.ibama.gov.br/residuos/areascontaminadas/banco-de-dados-nacional-sobre-areascontaminadas-bdnac > . Acesso 25 de jul. de 2017.

BRASIL, Ministério do Meio Ambiente. Cooperação Bilateral Brasil-Alemanha. Brasília DF, 2017. Disp. em: http://www.mma.gov.br/destaques/item/857-cooperacaobilateral-brasil-alemanha>. Acesso em: 08 ago. 2017

BRASIL, Ministério do Meio Ambiente. Resolução CONAMA $n^{\circ} \mathbf{2 7 3}$, de 29 de novembro de 2000 . Dispõe sobre prevenção e controle da poluição em postos de combustíveis e serviços. Brasília, DF, dez 2000. Disp. em: <http://www .mma.gov.br/port/conama/legiabre.cfm?codlegi $=271>$. Acesso em: 03 de agosto de 2017.

BRASIL, Ministério do Meio Ambiente. Resolução CONAMA $n^{\circ}$ 420, de 28 de dezembro de 2009. Dispõe sobre critérios e valores orientadores de qualidade do solo quanto à presença de substâncias químicas e estabelece diretrizes para o gerenciamento ambiental de áreas contaminadas por essas substâncias em decorrência de atividades antrópicas. Brasília, DF, dez 2009. Disp. em: < http://www.mma.gov.br/ port/conama/legiabre.cfm?codlegi=620>. Acesso em: 03 de agosto de 2017.

BRASIL, Presidência da República. Lei no 1413 de 31 de julho de 1975. Dispõe sobre o controle da poluição do meio ambiente provocada por atividades industriais. Brasília, DF, 1975. Disp. em: <http://www.planalto.gov.br/ccivil_03/leis/L6938.htm>. Acesso em: 15 fev. 2017 
BRASIL, Presidência da República. Lei $\mathbf{n}^{\mathbf{0}} \mathbf{6 9 3 8}$ de 31 de agosto de 1981. Dispõe sobre a Política Nacional do Meio Ambiente, seus fins e mecanismos de formulação e aplicação, e dá outras providências. Brasília, DF, agosto 1981 Disp.em: <http://www.planalto.gov.br/ccivil_03/leis/L6938.htm>. Acesso em: 15 fev. 2017.

BRASIL, Presidência da República. Lei no 9.605, de 12 de fevereiro de 1998. Dispõe sobre as sanções penais e administrativas derivadas de condutas e atividades lesivas ao meio ambiente, e dá outras providências. Brasília, DF, dez 1998. Disp. em: <http://www.planalto.gov.br/ccivil_03/leis/ L9605.htm>. Acesso em: 03 de agosto de 2017.

CONFEDERAÇÃO NACIONAL DA INDÚSTRIA. Perfil da indústria nos estados 2016. Brasília: CNI, 2016. Disp. em: $<$ http://perfilestados.portaldaindustria.com.br/estado/ap>. Acesso em: 17 jan. 2018.

EUROPEAN ENVIRONMENT AGENCY (EEA) Management of contaminated sites in Western Europe. European Environment Agency (EEA). 2000. Disp. em:<https://www.eea.europa.eu/publications/Topic_report_No _131999>. Acesso em: 12. Ago. 2017.

EUROPEAN ENVIRONMENT AGENCY (EEA). Progress in management of contaminated sites. European Environment Agency (EEA). 2014. Disp. em: <https://www.eea. europa.eu/data-and-maps/indicators/progress-in-managementof-contaminated-sites-3/assessment>. Acesso em 12. Ago. 2017.

INSTITUTO DE PESQUISA TECNOLOGICAS. Panorama do setor de gerenciamento de áreas contaminadas no Brasil. 1. ed. - São Paulo: IPT, 2016. Disp. em: < http://www.ipt.br/publicacoes/60.htm>. Acesso em: 08 jun. 2017.

LEPSCH, I. F. 19 Lições de Pedologia. 1ed. São Paulo: Oficina de Textos, 2011

MINAS GERAIS. FUNDAÇÃO ESTADUAL DO MEIO AMBIENTE - FEAM. Inventario de Áreas Contaminadas do Estado de Minas Gerais - 2016. Belo Horizonte: FEAM, 2016. Disp. em: <http://www.feam.br/images/stories/2016/ AREAS_CONTAMINADAS/INVENT\%C3\%81RIO_2016.pd $\mathrm{f}>$. Acesso em 22 abr 2017.

MOERI, E. N.; RODRIGUES, D.; NIETERS, A. Áreas Contaminadas: Remediação e Revitalização. São Paulo: Signus, 2007.

MORINAGA, C. M. Áreas contaminadas e a Construção da Paisagem Pós-industrial na Cidade de São Paulo. 2013. 200 p. Tese (Doutorado em Paisagem e Ambiente) - Faculdade de Arquitetura e Urbanismo, Universidade de São Paulo, São Paulo, 2013.

PANAGOS, P.; LIEDEKERKE, M.H.VAN; YIGINI, Y; MONTANARELLA, L. Contaminated Sites in Europe: Review of the Current Situation Based on Data Collected through a European Network. Journal of Environmental and Public Health. V. 2013, Article ID 158764, 11 pages. 2013. Disp. em: $<$ http://dx.doi.org/10.1155/2013/158764https://www.hindawi. com/journals/jeph/2013/158764/>. Acesso em: 03 ago. 2017.

POLICARPO, N. A. Tratamentos de Solos contaminados com Bifenilas Policloradas - PCBs. São Paulo 2008. Tese de Mestrado da Escola Politécnica da Universidade de São Paulo. RIO DE JANEIRO. INSTITUTO ESTADUAL DO AMBIENTE - INEA. Avaliação de Áreas Contaminadas. 2017. Disp. em: $<$ http://200.20.53.3:8081/Portal/MegaDropDown/Licenciamen to/GestaodeRiscoAmbientalTec/AvaliacaodeAreasContamina das/index.htm\&lang=> . Acesso em: 22 fev. 2017.

RIYIS, M.T.; MURARO, D.R.; HIRAI, E.Y.; LIMA, E.M. B.; CEOLIN, J.A.; JESUS, L.S. Avaliação das falhas no modelo conceitual de uma área contaminada utilizando investigação com métodos convencionais. InterfacEHS Saúde, Meio Ambiente e Sustentabilidade, São Paulo, v. 12, n. 1, p. 82-101, 2017.

SÃO PAULO, Lei $\mathbf{n}^{\mathbf{0}}$ 13.577, de 08 de julho de 2009. Dispõe sobre diretrizes e procedimentos para a proteção da qualidade do solo e gerenciamento de áreas contaminadas, e dá outras providências correlatas. São Paulo, jul, 2009. Disponível em: <http://www.al.sp.gov.br/repositorio/legislacao/lei/2009/lei13577-08.07.2009.html>. Acesso em: 22 fev. 2017.

SÃO PAULO. COMPANHIA AMBIENTAL DO ESTADO DE SÃO PAULO - CETESB. Áreas contaminadas críticas. São Paulo, 2016. Disp. em: <http://areascontaminadas.cetesb.sp .gov.br/category/areas-contaminadas-criticas/>. Acesso em: 20 out. 2016.

SÃO PAULO. COMPANHIA AMBIENTAL DO ESTADO DE SÃO PAULO - CETESB. CETESB Disponibiliza nova relação de área reabilitadas, monitoradas e contaminadas. São Paulo: CETESB, 2014. Disp. em: < http://www.cetesb.sp.gov.br/2014/06/02/cetesb-disponibilizanova-relacao-de-areas-reabilitadas-monitoradas-econtaminadas/>. Acesso em: 22 fev. 2017.

SÃO PAULO. COMPANHIA AMBIENTAL DO ESTADO DE SÃO PAULO - CETESB. Decisão da Diretoria n. ${ }^{\circ}$ 038, de 07 de fevereiro de 2017. Dispõe sobre a aprovação do "Procedimento para a Proteção da Qualidade do Solo e das Águas Subterrâneas", da revisão do "Procedimento para o Gerenciamento de Áreas Contaminadas" e estabelece "Diretrizes para Gerenciamento de Áreas Contaminadas no Âmbito do Licenciamento Ambiental”, em função da publicação da Lei Estadual $n^{\circ}$ 13.577/2009 e seu Regulamento, aprovado por meio do Decreto $\mathbf{n}^{\circ}$ 59.263/2013, e dá outras providências. São Paulo, 2017. Disp. em: http://www.cetesb.sp.gov.br/wp-content/uploads/sites/11/ 2014/12/DD-038-2017-C.pdf> . Acesso em: 01 jun. 2017.

SÃO PAULO. COMPANHIA AMBIENTAL DO ESTADO DE SÃO PAULO - CETESB. Decisão da Diretoria $\mathbf{n}^{\circ}$ 256/2016/E, de 22 de novembro de 2016. Dispõe sobre a aprovação dos "Valores Orientadores para Solos e Águas Subterrâneas no Estado de São Paulo - 2016” e dá outras providências. SÃO PAULO, 2016. Disp. em: <http://www.cetesb.sp.gov.br/wp-content/uploads/sites/11/ 2014/12/DD-256-2016-E-Valores-Orientadores-Dioxinas-eFuranos-2016-Intranet.pdf>. Acesso em: 22 fev. 2017.

SÃO PAULO. COMPANHIA AMBIENTAL DO ESTADO DE SÃO PAULO - CETESB. Decisão da Diretoria $\mathbf{n}^{0}$ 045/2014/E/C/I, de 20 de fevereiro de 2014. Dispõe sobre a aprovação dos Valores Orientadores para Solos e Águas Subterrâneas no Estado de São Paulo - 2014, em substituição aos Valores Orientadores de 2005 e dá outras providências. SÃO PAULO, 2014. Disponível em: $<$ http://www.cetesb.sp.gov.br/wp-

content/uploads/sites/11/2013/11/DD-045-2014-P53.pdf >. Acesso em: 22 fev. 2017.

SÃO PAULO. COMPANHIA AMBIENTAL DO ESTADO DE SÃO PAULO - CETESB. Decisão da Diretoria $\mathbf{n}^{\circ}$ 263/2009/P, de 20 de outubro de 2009. Dispõe sobre a aprovação do Roteiro para Execução de Investigação Detalhada e Elaboração de Plano de Intervenção em Postos e Sistemas Retalhistas de Combustíveis. São Paulo, 2009.

SÃO PAULO. COMPANHIA AMBIENTAL DO ESTADO DE SÃO PAULO - CETESB. Decisão da Diretoria n. ${ }^{\circ} 103$, de 22 de junho de 2007. Procedimento para Gerenciamento de Áreas Contaminadas. São Paulo, 2007. Disp. em: <http://cetesb.sp.gov.br/areas-contaminadas/wp-content/ uploads/sites/45/2015/07/DD-103-07-C-E-Procedimento-paraGerenciamento-de-\%25C3\%2581reas-Contaminadas.pdf $>$. Acesso em: 01 jun. 2017

SÃO PAULO. COMPANHIA AMBIENTAL DO ESTADO DE SÃO PAULO - CETESB. Decisão da Diretoria n. ${ }^{0}$ 010-2006C de 26 de janeiro de 2006. Dispõe sobre os novos Procedimentos para o Licenciamento de Postos e Sistemas Retalhistas de Combustíveis e dá outras providências. Disp. em: $<$ http://www.cetesb.sp.gov.br/licenciamento/documentos/decis ao_diretoria_26_01_06.pdf $>$. Acesso em: 22 fev. 2017.

SÃO PAULO. COMPANHIA AMBIENTAL DO ESTADO DE SÃO PAULO - CETESB. Manual de Gerenciamento de 
Áreas Contaminadas. São Paulo, 1999. Disp. em: $<$ http://areascontaminadas.cetesb.sp.gov.br/manual-degerenciamento/>. Acesso em: 22 fev. 2017.

SÃO PAULO. COMPANHIA AMBIENTAL DO ESTADO DE SÃO PAULO - CETESB. Relação de Áreas Contaminadas e Reabilitadas. São Paulo: CETESB, 2016. Disp. em: $<$ http://areascontaminadas.cetesb.sp.gov.br/relacao-de-areascontaminadas/> Acesso em: 22 fev. 2017.

SÃO PAULO. COMPANHIA AMBIENTAL DO ESTADO DE SÃO PAULO - CETESB. Técnicas de Investigação de Áreas Contaminadas: Solo. São Paulo: CETESB, 2016.

SÃO PAULO. Decreto 8469, de 8 de setembro de 1976. Aprova o Regulamento da Lei n. $^{\circ}$ 997, de 31 de maio de 1976, que dispõe sobre a prevenção e o controle da poluição do meio ambiente. São Paulo, set, 1976. Disp. em: <http://www.al.sp.gov.br/repositorio/legislacao/decreto/1976/ decreto-8468-08.09.1976.html> .Acesso em: 22 fev. 2017.
SÃO PAULO. Lei 997 de 31 de maio de 1976. Dispõe sobre o controle da poluição do meio ambiente. São Paulo, 1976. Disp. em: <http://www.al.sp.gov.br/repositorio/legislacao/lei/ 1976/lei-997-31.05.1976.html>. Acesso em: 22 fev. 2017.

UNITED STATES ENVIRONMENTAL PROTECTION AGENCY (USEPA). EPA's Report on the Environment (ROE). 2017. Ed. Washington, DC: United States Environmental Protection Agency, 2017. Disp. em: $<$ https://cfpub.epa.gov/roe/chapter/land/contaminated.cfm>. Acesso em: 03 ago. 2017.

Submetido em 9 de abril de 2018 Aceito para publicação em 11 de junho de 2020 